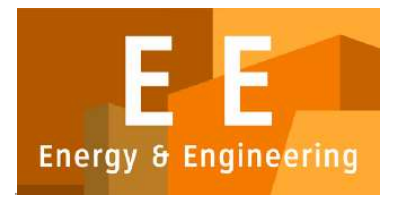

PAPER - OPEN ACCESS

\title{
Pasar Tradisional: Pilar Peradaban Yang Arif, Berbudaya Dan Kreatif Bagi Seluruh Generasi
}

\author{
Author : Annisa Aurindita Amelia \\ DOI $\quad: 10.32734 /$ ee.v3i1.857 \\ Electronic ISSN $\quad: 2654-704 \mathrm{X}$ \\ Print ISSN : :2654-7031
}

Volume 3 Issue 1 - 2020 TALENTA Conference Series: Energy \& Engineering (EE)

This work is licensed under a Creative Commons Attribution-NoDerivatives 4.0 International License.

Published under licence by TALENTA Publisher, Universitas Sumatera Utara 


\title{
jibli (4) TALENTA Conference Series
}

Available online at https://talentaconfseries.usu.ac.id/ee

\section{Pasar Tradisional: Pilar Peradaban Yang Arif, Berbudaya Dan Kreatif Bagi Seluruh Generasi}

\author{
Traditional Markets: Arif, Cultured And Creative Civilization Pillars For All Generations
}

\author{
Annisa Aurindita Amelia ${ }^{\mathrm{a}}$ \\ a Jurusan Arsitektur, Fakultas Teknik, Universitas Brawijaya, Lab Arsitektur Nusantara, Jl. MT Haryono No. 167 Malang
} aurinditaamelia31@gmail.com,arsftub@ub.ac.id

\begin{abstract}
Abstrak
Keberadaan pasar tradisional dalam kearifan budaya masyarakat Indonesia yang heterogen bukan hanya sebagai tempat jual beli, tetapi lebih dari itu, pasar tradisional merupakan wadah konsepsi kehidupan dan interaksi sosial budaya yang terjalin. ada nilai-nilai luhur dan kearifan lokal yang berkembang di pasar tradisional. tetapi di zaman modern banyak budaya tergeser oleh perkembangan dan arus modernisasi. salah satunya adalah budaya interaksi dan komunikasi dalam perdagangan. ketimpangan sosial jika berbicara tentang kepentingan pasar tradisional itu sendiri. Umumnya pasar tradisional hanya diminati oleh kalangan menengah ke bawah. Dengan segala stigma negatif kini budaya perdagangan di pas ar tradisional kini mulai kehilangan pamornya sebagai tumpuan utama perekonomian rakyat. Sehingga perlu adanya revitalisasi pasar tradisional melalui potensinya. Tiga potensi terkuat pasar tradisional adalah keragaman etnis dan budaya baik penjual maupun pembeli, kearifan lokal yang tumbuh bersama pelaku pasar tradisional yang menjadi ciri khasnya, dan kreativitas dalam menghadapi tantangan perubahan jaman, keragaman dan globalisasi.
\end{abstract}

Kata Kunci: Traditional Market, Cultural, Globalization;

\begin{abstract}
The existence of traditional markets in the cultural wisdom of heterogeneous Indonesian society is not just a place for buying and selling, but more than that, traditional markets are a container for the conception of life and social and cultural interaction intertwined. there are noble values and local wisdom that bloom in traditional markets. but in modern times many cultures are displaced by the development and current of modernization. one of which is a culture of interaction and communication in trading. social inequality when talking about the interests of the traditional market itself. generally the traditional market is only in demand by the lower middle class. with all the negative stigma now that the culture of trade in traditional markets is now starting to lose its prestige as the main base of the people's economy. so the need for revitalization of traditional markets through its potentials. the three strongest potentials of traditional markets are the ethnic and cultural diversity of both sellers and buyers, local wisdom that grows with traditional market actors that have become their trademarks, and creativity in facing the challenges of changing times, diversity and globalization.
\end{abstract}

Keywords: Traditional Market, Cultural, Globalization;

\section{Pendahuluan}

Ketika berbicara mengenai kearifan lokal dalam konteks berbudaya di Indonesia maka akan sedikit banyak berkaitan dengan interaksi sosial.

Pasar tradisional dalam hal ini merupakan wadah yang telah diwariskan oleh nenek moyang indonesia sejak jaman dahulu sebagai wadah, bukan hanya sebagai pusat perekonomian namun juga dari keberagaman interaksi sosialnya. Sehingga lambat laun pasar tradisional telah menjadi tempat bagi lebih dari lima puluh juta jiwa dalam menggantungkan hidupnya.

Tidak hanya sebagai basis ekonomi bagi sebagian masyarakat indonesia, namun juga sebagai basis tumbuhnya penghargaan terhadap nilai-nilai luhur, dan pelestarian kearifan lokal yang tidak dijumpai dalam interaksi sosial di pasar-pasar modern.

Bagaimana setiap komponen antar penjual melihat satu sama lain sebagai kawan dan mitra kerja bukan sebagai lawan atau saingan perdagangan. Berdagang menjadikan mereka terikat dalam persaudaraan. Seluruh aktivitas para pedagang pasar tradisional tersebut lah yang memupuk kesadaran akan toleransi, kerukunan, dan saling menolong dalam berusaha.

(C) 2020 The Authors. Published by TALENTA Publisher Universitas Sumatera Utara

Selection and peer-review under responsibility of Seminar Nasional Kearifan Lokal V 2020

p-ISSN: 2654-7031, e-ISSN: 2654-704X, DOI: 10.32734/ee.v3i1.857 
Di pasar tradisional interaksi sosial antar penjual dan pembeli sebagai sarana tawar menawar tidak hanya sebatas jual beli namun juga menjadi konsep dasar untuk saling memahami dan mengerti dalam menyenangkan hati dan menghargai satu sama lain. Ada rasa kepercayaan dan kejujuran yang dipelihara dalam hubungan ini.

Pasar tradisonal sekaligus menjadi ruang budaya dalam konsepnya 'Memanusiakan manusia'. Melunturnya tenggang rasa antar masyarakat saat ini seharusnya telah menjadi sebuah pengingat keras bahwa kepedulian telah lama menghilang dari prinsip bermasyarakat saat ini, yang akhirnya melahirkan sikap anarkis, mudah tersulut emosi, dan kemudian kemarahan yang menjadi penutup pintu toleransi dalam bermasyarakat di Indonesia.

Sayangnya saat ini pasar tradisional telah mengalami kekalahan dalam pamornya sebagai basis utama perekonomian rakyat. Globalisasi telah melahirkan bentukan baru hasil dari ambisi ekonomi rakyat yang terus tumbuh, yang dikenal sebagai pasar modern (mall dll.). padahal, sistem ekonomi di pasar modern sama sekali tidak memberikan kepuasan dalam pengaruhnya terhadap berbudaya.

Minimnya interaksi - komunikasi antar pedagang dan pembeli, minimya tata krama dalam bertransaksi sangat mendorong jatuhnya nilai-nilai kekeluargaan maupun kearifan lokal pasar yang telah ditanamkan oleh orang dahulu (leluhur).

Atas nama tuntutan, pasar modern telah mengajarkan masyarakat akan pragmatisasi dalam berinteraksi. Sebab, interaksi di pasar modern hanyalah sebatas pemenuh kebutuhan pokok. Namun, kehadiriannya telah ada dan tidak bisa ditolak lagi karena globalisasi pasti cepat atau lambat akan terjadi. Terlepas dari sisi positif maupun negatif dari pasar modern. Eksistensi pasar modern secara perlahan menggerus keberadaan pasar tradisional dengan segala keanekaragaman dan keunikan didalamnya.

Bukankah pasar tradisional memiliki keterkaitan yang erat terhadap kebudayaan suatu bangsa. Didalam Undang-Undang Dasar 1945 pasal 32 disebutkan bahwa masyarat dijamin kebebasannya dalam memajukan budaya nasional.

Interaksi langsung masyarakat di pasar tradisional mampu menciptakan gagasan dan memperluas wawasan yang di simpan oleh setiap individu kemudian diaplikasikan pada nilai dan norma yang berlaku dilingkungannya. Melalui proses asimilasi dan akulturasi gagasan - gagasan yang terlahir dari kebijaksanaan, dan kearifan masyarakat itu lah kearifan lokal terbentuk.

Salah satu aset penting budaya suatu bangsa adalah kearifan lokal karena dengannya perbaikan kualitas hidup masyarakatnya terdefinisi. Dan tidak menutup kemungkinan untuk menjadikan kearifan lokal menjadi suatu bagian dari perencanaan ketika esensinya masih memiliki relevansi yang kuat terhadap permasalahan yang masih dihadapi saat ini (present problem solving).

Mengapa pasar tradisional penting untuk tetap ada ? Karena pasar tradisional merupakan ruang publik yang bebas dan tempat bagi masyarakat untuk berdagang, berinteraksi dan berkumpul. Karena ketersediaan ruang dan kemudahan aksesnya, hal ini serupa dengan teorinya "Dasar dan arah yang dituju dalam perencanaan kebudayaan adalah manusia itu sendiri sehingga humanisasi menjadi kerangka dasar dalam strategi kebudayaan" (Ali Moertopo, 1978;12) ${ }^{[1]}$. Aktivitas publik sungguh menjadi nyta ketika dihubungkan dengan masyarakat yang heterogen dan aktivitasnya di pasar tradisional.

Pasar tradisional menjadi tempat strategis untuk mengakses seluruh lapisan masyarakat secara langsung dan intensif. Hal ini tercermin dalam sejarahnya bagaimana islam secara konsisten melakukan penyebaran keyakinan dalam beragama islam melalui perantara kegiatan jual belinya di pasar-pasar tradisional. Sehingga validitas akan pengaruh interaksi sosial yang kuat di pasar tradisional dapat terbuktikan.

Keuntungan lain dengan mempertahankan keberadaan pasar tradisional adalah karena dapat menghasilkan keuntungan materil bagi negara melalui sistem retribusi dari para pedagang pasar. Mendatangkan pajak untuk negara berupa PAD (Pajak Asli Daerah). Pasar juga merupakan sentra usaha mikro kecil dan menengah (UMKM). Pada beberapa kasus keterbatasan modal banyak menghambat wiraswasta muda untuk berkembang.

Pasar tradisional juga memiliki kebermanfaatannya dalam bidang pendidikan. Pasar tradisional mengajarkan masyarakat secara budaya untuk bertindak dengan persaingan yang sehat dalam berkompetisi. Pasar tradisional yang mayoritas pedangangnya adalah pedagang kecil (Omset kecil) jarang terjadi tindakan monopoli perdagangan dalam artian barang yang penahanannya akan membahayakan konsumen dan orang banyak sehingga praktis menjadi arena perdagangan efektif bagi pemula.

Partisipasi masyarakat sangatlah diperlukan dalam menjaga keberhasilan pasar tradisional untuk bertahan, berkembnag, dan mencapai bargaining positiion dalam menghadapi setiap krisis perdagangan. Dengan lebih banyak masyarakat yang sadar akan pentingnya memilih pasar tradisional sebagai sandaran berbelanjannya maka usaha masyarakat pedagang menengah kebawah di pasar tradisional akan mengalami perkembangannya. Dengan begitu negara akan memenuhi tujuannya dalam pemerataan pendapatan rakyat hingga menguatkan ekonomi dan keejahteraan negara.

Untuk menjaga agar pasar tradisional tidak melemah maka potensi-potensi pasar harus diimplementasikan dengan taktik yang benar. Dukungan kumulatif tidak hanya datang dari para konsumen namun juga dibutuhkan bantuan dari pihak pemerintah untuk mulai memperbaiki kebutuhan penunjang pasar tradisional antara lain adalah fasilitasmgedung, sanitasi, standar keamanan, dan sarana prasarana. Kemudian memperbaiki konsistensi regulasi dalam hal perizinan sehingga tidak melahirkan persaingan usaha tidak sehat. Bagaimanapun, kejahatan dan ketidak adilan terjadi hanya ketika ada sebuah peluang itu sendiri. 


\section{LANDASAN TEORI}

\subsection{Pasar Tradisional}

Secara terminologi kata, pasar adalah tempat perjumpaan antara pembeli dan penjual, dimana barang atau jasa dipertukarkan antara pembeli dan penjual. Ukuran tingkat kerelaan pertukaran barang ditentukan berdasarkan tingkat harga barang dan jasa yang dipertukarkan tersebut (Ehrenberg at al., 2003).

Proses pertemuan hingga terjadi kesepakatan itulah yang membentuk pasar. Pasar tersebut tidak memperhatikan tempat dan jenis barang. Jadi pasar tidak terbatas pada suatu lokasi saja (Rasyaf, 1996).

Pasar tradisional terjadi karena dalam pelaksanaannya bersifat tradisional berupa pertemuan langsung antara penjual dan pembeli. Proses pelaksanaan ini termasuk tawar-menawar harga barang karena harga bukan harga tetapsehingga kondisi ini sangat berbeda dengan pasar modern (M. Fuad, 2000). Bentuk pasar tradisional berupa bangunan kios-kios dan gerai dan menyediakan bahan pokok rumah tangga.

Berdasarkan Permen RI Nomor 20 tahun 2012 pasal 4, dikatakan kriteria pasar tradisional antara lain, milik pemerintah, transaksi secara tawar menawar, barang yang ditawarkan adalah bahan baku lokal.

\subsection{Kearifan Lokal}

Berdasarkan penelitian Putra (2009) kearifan lokal fokus kepada lokasi dan lokalitas, dari kearifan tersebut, sehingga kearifan lokal tidak harus tradisi yang diturunkan dari generasi ke generasi ${ }^{[1]}$. Kearifan lokal juga kearifan yang belum lama timbul pada komunitas, sebagai hasil dari integrasi dengan lingkungan alam, masyarakat dan budaya lain. Olah karena itu kearifan lokal tidak selalu bersifat tradisional, karena bisa merupakan kearifan local sekarang. Untuk membedakan antara kearifan lokal yang baru dalam suatu komunitas dengan yang lama, dapat disebut ' kearifan kini', 'kearifan kontemporer', dan 'kearifan tradisional' atau 'kearifan lama'.

Kearifan local termasuk beragam pengetahuan, cara pandang, nilai dan prilaku komunitas baik yang diperoleh dari generasi generasi sebelumnya. Dari komunitas tersebut, yang bukan berasal dari generasi sebelumnya, tetapi dari beragam pengalaman sekarang, termasuk juga hubungannya masyarakat atau budaya lain. Oleh karena itu kearifan lokal dapat didefinisikan sebagai pengetahuan dan prilaku dalam suatu komunitas baik yang lama maupun yang kontemporer untuk menyelesaikan secara baik dan benar persoalan dan/atau kesulitan yang dihadapi, yang memiliki kekuatan seperti hukum maupun tidak.

\subsection{Kebudayaan Berbudaya}

Ada beberapa pengertian budaya menurut beberapa ahli . Berdasarkan Koentjaraningrat (2000: 181) kebudayaan berasal dari bahasa sansekerta "buddhayah", yaitu bentuk jamak dari buddhi yang berarti 'budi' atau 'akal'. Budaya dikatakan sebagai cipta, karsa dan rasa dan kebudayaan adalah hasilnya. Kebudayaan merupakan gagasan, karya manusia. Dibedakan bentuk kebudayaan menjadi tiga yaitu : pertama, wujud ide, gagasan, nilai, norma dan aturan. Kedua, aktivitas dan pola dari individu. Ketiga, benda hasil cipta manusia.

Defenisi kebudayaan berbeda menurut (Liliweri, 2002); dan (Hawkins, 2012). Pandangan hidup individu dalam bentuk prilaku, agama, nilai dan simbol yang diinterpretasi dari komunikasi antar generasi. Bentuk-bentuk kesamaan antar generasi itulah yang disebut teknologi, pengetahuan, agama, hukum, estetika dan kebiasaan. Sedangkan (Hawkins, 2012) mendefenisikan budaya melalui pengetahuan, agama, seni moral dan tradisi yang dimiliki manusia.

Berbeda sedikit dengan kedua pakar diatas, (Ihromi, 2006) mengartikan kebudayaan sebagai cara-cara, kepercayaan, sikap yang menjadi hasil kegiatan manusia yang khas dalam masyarakat.

\subsection{Kreativitas}

Kreativitas ternyata mempunyai pengertian yang beragam. Ada dua pakar yang menyatakan kreativitas dengan pendekatan yang sama yaitu baron dalam (Ali \& Arori, 2006) dan Drevdaahl dalam (Hurlock, 1978). Muharwati (2014) mengatakan bahwa kreativitas mempunyai definisi yang banyak sekali. Kemampuan menciptakan suatu yang baru dikatakan sebagai kreativitas oleh Baron. Kemampuan menciptakan produk dan komposisi (berupa produk seni, sastra, ataupun prosedural ) yang baru juga kreativitas menurut Drevdaahl.

Kreativitas juga memiliki dua cara berfikir yaitu konvergen dan divergen. Konvergen adalah cara berfikir dengan hanya satu jawaban yang benar sedangkan divergen mempunya beberapa alternatif solusi dikatakan oleh Guilford dalam (Ali dan Asrori, 2006). Seseorang dikatakan kreatif bila berfikir secara divergen dibandingkan dengan konvergen.

Torrance dan (Munandar, 2002) mengartikan kreativitas dengan melihat dari sudut pandang yang berbeda. Kalau Torrance melihatnya dari proses memahami kesenjangan dan hambatan dalam hidup sedangkan Munandar melihatnya dari kelancaran dan fleksibilitas dalam berfikir. 
Kreativitas juga mempunyai proses penciptaan yang didahului dengan persiapan, inkubasi, iluminasi dan verivikasi. Ada faktor pendorong kreativitas berupa internal ( keinginan dan hasrat untuk menciptakan diri secara kreatif) dan eksternal (lingkungan sosial dan psikologis). Kalau semua pendapat pakar itu disimpulkan, dapat dikatakan bahwa kreatif adalah kemampuan menghasilkan suatu gagasan dengan berbagai macam alternatif dan beberapa proses kreatif yang didukung oleh lingkungan sekitar.

\subsection{Interaksi Sosial}

Interaksi sosial merupakan hubungan antar individu -individu, antar kelompok-kelompok maupun antar individu-kelompok yang bersifat dinamis. Proses interaksi sosial berdasarkan makna sesuatu bagi manusia yang bisa saja berubah. Interaksi sosial terjadi biala ada komunikasi. Komunikasi terjadi berawal dari sumber informasi (ciri fisik dan penampilan) individu. Masing-masing individu mempunyai ciri fisik (jenis kelamin, usia, ras) dan penampilan (daya tarik fisik, bentuk tubuh, cara berbusana) yang berbeda.

Berdasarkan Robert T Hall, aturan interaksi sosial dapat dilihat dari Dimensi Ruang dan Dimensi waktu. Dimensi Ruang yaitu terbagi atas empat batasan jarak yaitu jarak yatim, pribadi, sosial dan publik. Dimensi waktu yaitu batasan toleransi waktu. Sedangkan WI thomas mengatakan aturan interaksi sosial dapat dilihat dari Defenisi Situasi yaitu yang dibuat oleh individu dalam masyarakat.

Generasi adalah sekumpulan orang yang sama umur dan pengalaman historisnya (Manheim,1952). Kumpulan orang tersebut juga memiliki tahun lahir dan 20 tahun rentang waktu yg sama berarti dimensi sosial dan sejarah yang sama. Pernyataan ini juga didukung oleh (Ryder, 1965) yg menyatakan kumpulan orang-orang tersebut juga mengalami kejadian dan waktu yang sama pula.

\section{Pembahasan}

\subsection{Pasar Tradisional Sebagai Pilar Peradaban Budaya, Kearifan Lokal, dan Kreativitas Bagi Seluruh Generasi}

Sebuah pasar terbentuk dari ruang yang diciptakan oleh aktivitas jual dan beli suatu masyarakat sehingga terjadi kesepakatan antara keduannya. Pada dasarnya pasar tradisional merupakan representasi dari ekonomi rakyat, ekonomi kelas bawah, sebagai tempat bergantung para pedagang kecil dan menengah. Bukan hanya itu, pasar tradisional telah lama menjadi tumpuan harapan kaum produsen seperti petani, peternak, pengrajian dan produsen lainnya selaku pemasok.

Ruang dari miniatur kebudayaan indonesia ini menjadi ruang bagi keberagaman (multikultural), dan sebagai contoh nyata kebhinekaan bangsa indonesia. Banyak etnis dan suku dengan karakter khas dan kebudayaannya masing-masing yang berjumpa kemudian belajar untuk saling hidup berdampingan dan mencari nafkah dalam kios-kios maupun lapak-lapak kecil yang ada di pasar tradisional.

Setiap pedagang memiliki keunikannya sendiri dalam berdagang dan menawarkan dagangannya, namun harmonisasi tetap terdengar dengan baik karena prinsip tenggang rasa yang telah berakar diantara para pedagang.

Dipasar tidak ada budaya minoritas atau mayoritas, artinya tidak ada dominasi budaya lain selain budaya 'pedagang pasar'. seperti kata pepatah "dimaan bumi dipijak, disitu langit dijunjung" begitu pula bagaimana masyarakat heterogen di pasar tradisional saling menjaga interaksinya antara satu dengan yang lain.dapat dikatakan bahwa, area pasar telah sukses menjadi tempat bagi pembauran berbagai macam etnis, baik etnis Tionghoa, Arab, Gujarat,India, dan etnik yang berasal dari wilayah nusantara. Pasar tradisional dalam konteks ini benar-benar menjadi perekat identitas budaya bangsa yang sejalan dengan sesanti "Bhinneka Tunggal Ika" berbeda beda tetapi tetap satu.

Brata (2012) dalam jurnalnya memberikat contoh konkret dalam hal in. Para pedagang dituntut memiliki kemampuan merayu pembeli untuk memengaruhi dan meluluhkan hati pembeli dengan menggunakan bahasa atau simbol-simbol kesukuan. Seorang pedagang bali akan mencoba merayu pembeli jawa dengan berusaha untuk berhasa dan berlogat jawa. Para konsumen juga melakukan hal yang serupa, dengan sapaan -sapaan yang umum dipakai oleh sesama pedagang walaupun mereka bukan berasal dari kalangan tersebut.

Sapaan-sapaan sederhana itu sesungguhnya bermaksud merayu agar pembeli dapat dikenakan biaya yang lebih murah. Apabila lebih dicermati sapaan-sapaan tadi sesungguhnya terimplikasi suatu makna sebagai bentuk penghargaan dan sebuah keinginan untuk menjadi bagian dari heterogensi kebudayaan itu sendiri. Di samping itu, sapaan-sapaan tadi juga mengandung makna sebagai pengingat akan akar budaya para pelaku pasar oleh sesama meraka.

Kearifan lokal solidaritas antar pedagang juga sangat tinggi di pasar tradisional. Apabila salah seorang pedangang menemui hambatan atau halangan maka pedagang lain akan dengan senang hati menjaga dagangan satu sama lain juga dalam melayani pembeli meskipun itu bukan membeli dagangannya. Para pedagang saling gotong royong dalam memuaskan kebutuhan pembeli, terbukti ketika ketidak tersediannya suatu barang di kios satu maka kios lain akan membantu dalam memenuhi kebutuhan pembeli itu. Artinya konsep kejujuran dalam berdagang pun dilestarikan di pasar tradisional. 
Pasar tradisional dengan masyarakatnya yang heterogen sangat besar berpengaruh terhadap basis ekonomi. Sehingga harus diimbangi oleh pemutakhiran secara berkala dan terus menerus dalam memenuhi kebutuhan konsumen. Kreatifitas adalah kunci bagaimana pasar tradisional dan budayanya

tidak termodernisasikan. Pengembangan kreatifitas dalam hal komunikasi dan interaksi dalam berdagang dapat menjadi katalisator penting. Kreatifitas juga dapat menjawab bagaimana hambatan dapat berubah menjadi tantangan. Tantangan akan stigma negatif yang terus berkembang di tengah tengah globalisasi masyarakat tentang pasar tradisional yang terkenal dengan kumuhnya dan juga kriminalitasnya yang tinggi.

Sehingga kemudian menjadi penting untuk mempertimbangkan kebenaran pendapat yang ditutukan oleh Suwaji Bastomi (2003) bahwa kebudayaan itu tergerus bukan oleh karena artefak budayanya yang hilang, namun karena mentalitas masyarakatnya yang rendah dan inferior.

Maka, penting bagi setiap kalangan generasi bangsa indonesia untuk terus melestarikan kebudayaan, kearifan lokal, dan kreativitasnya melalui Pasar tradisional.

\subsection{Pasar Tradisional Dalam Menjawab Tantan Arus Globalisasi}

Pasar tradisional kerap identik dengan istikah tempat kotor, kumuh, semrawut, becek, bau, sumpek, sumber kemacetan, sarangpreman, dan masih banyak lagi. Kesimpulannya pasar tradisional erat dengan stigma negatif. Kesan buruk ini menyebabkansebagian kalangan masyarakat, kaum menengah keatas dan generasi muda timbul rasa enggan dan cenderung menghindari untuk berbelanja atau sekedar melewati pasar tradisional.

Untuk mempertahankan pasar tradisional, sebaiknya bentuk dan orientasi tetap mengacu kepada perilaku konsumen. Konsumen dalam membeli barang dipengaruhi dua faktor yaitu eksternal ( kebudayaan, kelas sosial, dan keluarga ) dan internal ( kepribadian dan karakteristik konsumen ). Pada beberapa kelompok masyarakat, pasar tradisional masih dibutuhkan karena barang yang dijual relatif murah.

Pasar tradisional dewasa ini juga rata-rata telah tebangun menjadi satu kesatuan bangunan yang utuh. Namun bukan artinya hal ini telah menjawab tantangannya dalam menghadapi globalisasi. Karena, miss treaten dalam sistem yang tercipta dalam bangunan masih terbilang cukup tinggi. Salah satu contohnya, pembagian kios dagang berlandaskan harga sewa bukan berdasarkan kelompok jualnya. Kerugiannya adalah, komunikasi antar komunitas dagang terhambat. Kearifan lokal yang seharusnya menjadi tinggi dalam berdagang menjadi rendah karena ketika komunikasi gagal untuk terbentuk lahir lah sebuah kegagalan dalam tindakan dan tindakan yang salah melahirkan sebuah kebiasaan yang salah juga. Dalam menghadapi tantangannya sangat bijak bukan hanya mempertimbangkan masalah fisik namun juga budaya non fisiknya.

Pada masa sekarang ini, pasar tradisional sudah hampir kalah pamornya dengan pasar modern. Diperlukan strategi manajemen profesional pasar tradisional supaya dapat bertahan pada kondisi sekarang ini. Mengacu kepada PP No. 112 tahun 2007 tentang penataan dan pembinaan pasar tradisional dan Permen Perdagangan RI no. 53/M-Dag/Per/12/2008 tentang pedoman penataan dan pembinaan pasar tradisional dan Permen Dalam Negeri RI no. 20 tahun 2012 tentang pengelolaan dan pemberdayaan pasar tradisional mengatur rencana tata ruang wilayah dan zonasinya. Dengan pengaturan ini maka sebaran lokasi pasar tradisional dan pasar Modern disetiap wilayah tetap terjaga.

Dengan pemberdayaan terhadap pasar tradisional dapat tumbuh dan berkembangditengah perkembangan globalisasi modernitas. Khususnya tidak menjadi mati karena keberadaan pasar modern, sehingga keduanya sepatutnya saling memperkuat, saling menguntungkan, dan dapat memajukan prekonomian negara.

Peraturan perundang undangan diatas juga memberikan kewenangan kepada daerah untuk dapat menata dan mengolah pasar tradisional maupun pasar modern agar keduanya tidak saling menyingkirkan dan 'mematikan'. kebijakan keleluwasaan dalam menata dan mengolah pasar tradisional ini pula dapat menjadi batu loncatan bagi Pemda dan pihak terkait agar dapat lebih menyentuh kebutuhan aspek sosial berbagai generasi. Bagaimana pasar tradisional dapat menyentuh minat generasi muda sebagai agen revitalisasi pasar tradisional yang paling efektif. Dan bagaimana pasar tradisional dapat mempertahankan sikap dan prinsip generasi tua dan menengah dalam melestarikan budaya dan kearifan lokal dalam melakukan perdagangan di pasar tradisional.

Perlindungan kebijakan terhadap Pasar tradisional dalam menghadapi globalisasi dan liberalisasi perdagangan telah memiliki pengaruhnya yang besar bagi tatanan pembangunan ekonomi terutama pada indutri kecil. Perkembangan kegiatan ekonomi skala besar mengakibatkan terganggunya kesejahteraan ekonomi masyarakat skala kecil. Dan akhirnya kegiatan ekonomi skala kecil yang sebagian besar terdapat pada pasar tradisional mulai ditinggalkan dan terpinggirkan.

\section{Kesimpulan}

Eksistensi pasar tradisional dalam kearifan budaya yang penuh akan keberagaman di Indonesia bukan sekedar tempat jual beli (Materiil) semata, namun lebih dari itu pasar tradisional merupakan suatu wadah atas konsepsi berkehidupan dan interaksi sosial budaya. Dalam lingkup pasar tradisional modernitas adalah hal yang tidak bisa dihindari namun dalam hal ini justru akan menjadi suatu 
tantangan tersendiri bagi setiap lapisan generasi dalam mempertahankan kebudayaan berdagang di pasar tradisional dan mengembangkan kreatifitasnya dalammenjawab tantangan globalisasi dan liberalisasi terhadap keberlangusngan aktivitas pasar tradisional. Usaha terpenting adalah bagaimana cara untuk menemukan solusi terhadap permasalahan stigma negatif dan egogap antara masyarakat kalangan atas dankalangan bawah sebagai penikmat pasar tradisional melalui potensi potensi yang dimiliki oleh pasar tradisional itu sendiri, seperti keberagaman budaya, kelestarian kearifan lokal, dan kreativitas yang terus terbarukan

\section{Referensi}

[1] Aliyah, Istijabatul, Setioko, Bambang\&Pradoto, W. 2015. Eksistensi pasar tradisional dalam kearifan budaya jawa. Jurnal Seminar NasionalPDTAP, 1-17.

[2] Brata, Ida bagus. 2007. Pasar Tradisional di Tengah Arus Budaya Global. Jurnal FKIP Universitas mahasaraswati Denpasar, 1-12.

[3] Putra, Heddy S. A. 2009. Bahasa, Sastra, dan Kearifan Lokal di Indonesia. Malakah seminar nasional Kantor bahasa NTB, 1-28.

[4] Seran, Marcel. 2014. Perlindungan Hukum Bagi Pasar Tradisional di Era Globalisasi dan Liberalisasi Perdagangan. MMH, 43 (3), 1-8.

[5] Putra, Yanuar S. 2016. Theoritical Review : Teori Perbedaan Generasi. Jurnal Among Makarti 9 (18), 1-12.

[6] Pasar tradisional sebagai rumah budaya,2010. (https://www.badriologi.com/2010/05/pasar-tr adisional-sebagai-rumah-budaya.html). diakses pada 29 november 2019.

[7] Menanamkankearifanbudayalocalpasar tradisional dimasyarakat (https://www.kompasiana.com/fathya17671/5c6d66a643322f573013dfb6/menanamkan-keari fan-budaya-lokal-pasar-tradisional-di-masyara kat) diakses pada 29 november 2019.

[8] Pasar tradisional menyimpan kearifanlokal, -. (https://www.bejiharjo-karangmojo.desa.id/fir st/artikel/169-Pasar-Tradisional-Menyimpan-Kearifan-Lokal-) diakses pada 29 november 2019.

[9] Melestarikanpasartradisionalmelestarikan budaya bangsa,(https://nationalgeographic.grid.id/read/13305 618/melestarikan-pasar-tradisional-melestarik an-budayabangsa?page=all) diakses pada 29 november 2019.

[10] Pasartradisionalmenjadipasarpesona budaya,--

(https://www.kompasiana.com/satriya1998/55 09a02ca3331179702e3aaf/pasar-tradisional-m enjadi-pasar-pesona-budaya ) diakses pada 29 November 201 